\title{
COVID-19 in Algeria: The Variants and the Risk of a Third Wave
}

Mohamed Lounis ${ }^{1 *}$

1 Department of Agro-veterinary Science, Faculty of Natural and Life Sciences, University of Ziane Achour, Djelfa, ALGERIA

* Corresponding author:

lounisvet@gmail.com

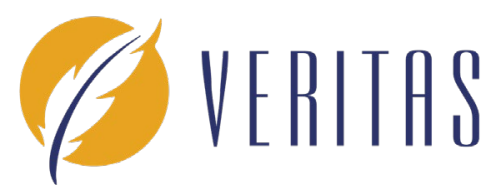

\section{EUROPEAN JOURNAL OF BASIC MEDICAL SCIENCE}

Eur J Basic Med Sci 2021;11(3):27-29

Received: 19 Jun 2021

Accepted: 24 Jul 2021

\section{ABSTRACT}

The objective of this work is to describe the emergence of the new variants on coronavirus in Algeria and the risk of a third wave of the COVID-19 disease.

Keywords: COVID-19, Algeria, new variants, third wave 


\section{Dear Editor,}

The humanity will never forget the year 2020, where a new coronavirus disease called COVID-19 has spread in all countries around the world [1]. This viral disease which has emerged in the City of Wuhan in China in December 2019 has been attracted until now by more than 150 millions persons leading to 3.1 millions deaths. The good news is that the number of recovered which has reached to 129 million [2].

Algeria like other countries has reported its first case on February $25^{\text {th }}, 2020$. Since then, the number is still increasing reporting until now 122108 cases and 3.253 deaths [3]. However, the evolution of the disease has shown multiple facets in relation with the applied preventive measures. The epidemiological curve has shown until now tow important peaks. One first peak in the months of June-July and the second in the last September 2020. these peaks were principally associated with the alleviation of the preventive actions. In fact, Algeria was one of the first northern African countries to close their border and to decrease the state of emergency since March, $12^{\text {th }} 2020$ with closure of schools, universities and national/partial containment. These measures which were classified as drastic by the Oxford Government COVID-19 Stringency Response Tracker (OxCGRT (index of 92 in a scale of 100)) [4] were accompanied by a relative control in the two first months. This period has been however followed by an increasing of the daily cases in the last of June and the beginning of July reaching a number of 675 cases on July $24^{\text {th }}, 2020$. These numbers have been associated with a saturation of hospital capacities in certain departments [5]. This peak was due principally to the alleviation of preventive measure. The second peak was reported in the months of NovemberDecember and was more important than the first one reporting the highest number of daily cases of 1133 case in November, $24^{\text {th }} 2020$. This number is also associated with the increasing of testing capacities from 50 test/day in the first period to more than 2500 tests/days.

In the three last months, the situation seemed to bee in a relative stability characterized by the diminution of hospitalized cases and the decreasing of confirmed cases reporting the lowest number since about a year in March $28^{\text {th }}, 2021$ (86 new cases/day) despite the low vaccination number (about 75000 vaccinated persons ( $<00.1 \%$ of the total population) [6]. These diminution has been followed by an and alleviation of leaving of containment in most of departments except some departments $(9 / 58)$ where the curfew is conducted from $00 \mathrm{PM}$ to $4 \mathrm{AM}$. This decreasing of number is of cases has been associated by some researchers the fact that the borders are still closed contrarily the neighboring countries of Tunisia and Morocco where the number has shown a net increasing in the last months. This "incomprehensive" decreasing has pushed some

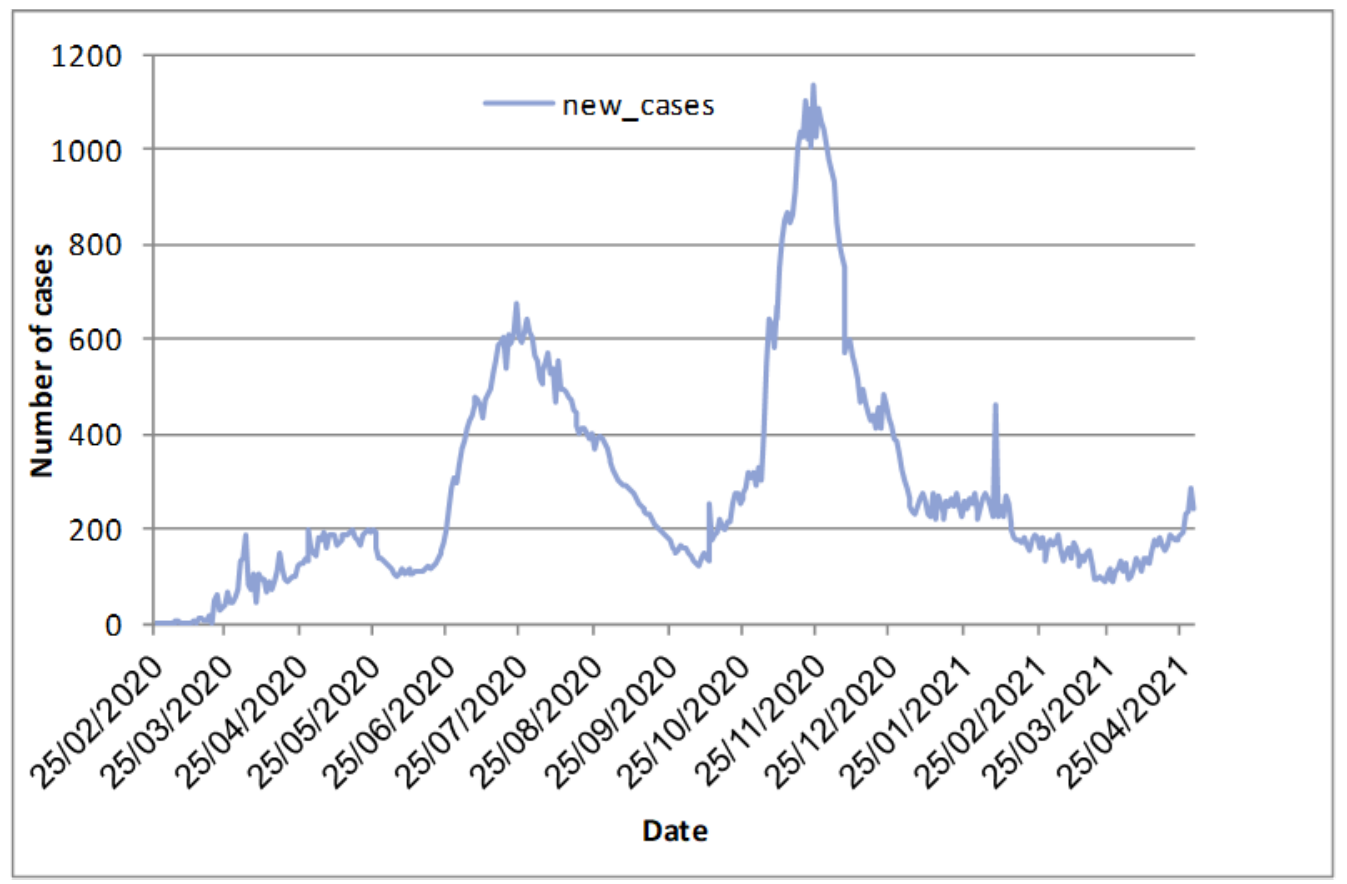

Figure 1. COVID-19 daily cases in Algeria 
specialists to adopt the theory of herd immunity estimating that the low number of declared cases is just related the weak testing capacities and also to the high number of asymptomatic cases. In a pilot study, it has been shown that in a serological survey of 1000 parsons, $50 \%$ among them were affected [7]. However, despite the border closure, Algeria reported the first cases affected by the British (B.1.1.7) on February $25^{\text {th }}$, in the department of Algiers March and the Nigerian variants (B.1.525) on March 11 th 2021 [8]. The Nigerian variant was first reported in the departments of Algiers, the east border departments of Tebessa and Souk Ahras and the southeast departments of Ouargla and In Salah. Since then, the number of cases is in a net increasing in association with an increasing of daily cases and hospitalized persons reporting a number of $286 /$ days on April, 2021, a number which was not reported since January $1^{\text {st }}, 2021$ (287 cases). The total number of cases affected by the British and the Nigerian variants has reached 143 and 230 cases respectively. The most affected department by the British variant are Algiers, Blida and Oran in the North while the most affected by the Nigerian variant are Algiers, Laghouat, Eloued, Oran and Medea.

The question is now what will be the evolution of these strains in Algeria and what will be the preventive actions against?. The first measures have been applied on April, $29^{\text {th }} 2020$ where the curfew were renewed in 19 departments.

Conflict of Interest: None to Declare

Source of funding: No funding

\section{REFERENCES}

1. Lounis M, 2020. A Descriptive Study of the Current Situation of COVID-19 in Algeria. Electron J Gen Med; 17(6): em253. doi: 10.29333/ejgm/8287.

2. Worldometer. 2021. Available at: https: / /www.worldometers.info/coronavirus/

3. Algerian health and hospital reform minister, 2020: Carte épidémiologique. Available at: https://www.covid19.gov.dz/carte/

4. Oxford Government COVID-19 Stringency Response Tracker. Available at: https://covidtracker.bsg. ox.ac.uk/stringency-scatter

5. coronavirus algérie: quelles solutions pour le surcharge les hôpitaux? [coronavirus algeria: what solutions for overloading hospitals?]. Available at: https: / /www.algerie360.com/20200703-lasurcharge-des-hopitaux-quelles-solutions/

6. Coronavirus (COVID-19) Vaccinations. Available at: https: / / ourworldindata.org/covidvaccinations? country $=\sim$ DZA

7. Immunité collective des Algériens face au Covid: l'idée gagne du terrain [Collective immunity of Algerians to Covid: the idea is gaining ground]. Available at: https://www.tsaalgerie.com/immunite-collective-des-algeriensface-au-covid-lidee-gagne-du-terrain/

8. Available at: https://pasteur.dz/fr/dz 